\title{
Effects of $\alpha \beta$-amirona on inflammation in topical edema ear model in mice
}

\author{
Natália Ferreira $^{1 *}$, Rafael Monteiro ${ }^{1}$, Geane Lourenço ${ }^{2}$ \\ From 5th Congress of the Brazilian Biotechnology Society (SBBIOTEC) \\ Florianópolis, Brazil. 10-14 November 2013
}

\section{Introduction}

In vivo models of inflammation are definitely the best tools to study the biological role, because no other approach will allow the simultaneous investigation of cells and mediators that interact during the inflammatory process. Several reports in the literature have shown the efficacy of $\alpha, \beta$-amyrin, the main component of the resin plant of the genus Protium in studies with in vitro models of inflammation. Another component of this resin with anti-inflammatory activity is the $\alpha \beta$-amirona, but this is still less studied.

Objective: To evaluate the topical anti-inflammatory activity of the compound isolated $\alpha \beta$-amirona in models of skin inflammation in mice.

\section{Methods}

We used 30 male mice of the Balb-c strain weighing 30-35g were divided into 6 groups (control phenol, treated with the extract at concentrations of $0.6 \mathrm{mg} / \mathrm{ear}$, $0.3 \mathrm{mg} /$ ear, $0.1 \mathrm{mg} /$ ear and control ears treated with dexamethasone). Edema was induced by topical application of $10 \%$ phenol in acetone $(20 \mathrm{~mL} / \mathrm{ear})$ on the right ear of all groups. The extract (0.6, 0.3 and $0.1 \mathrm{mg} /$ ear) or dexamethasone $(0.1 \mathrm{mg} / \mathrm{ear})$ was used as positive control, were applied directly after phenol. The left ear of each animal was used as a control for evaluation of edema. One hour after treatment, the animals were anesthetized with thiopental $80 \mathrm{mg} / \mathrm{kg}$ and sacrificed by intracardiac injection of potassium chloride $3 \mathrm{M}, 5 \mathrm{~mm}$ circles were taken from their ears with the aid of a punsh biopsy and weighed on an analytical balance. Evaluation edema was taken as the difference in weight of the tissue samples.

\section{Results}

The group of animals that received topical treatment with solution of $\alpha \beta$-amirona exhibited a decrease in edema induced by phenol when compared to the control group. However, the positive control group that was treated with dexamethasone showed a sharper decrease edema.

\section{Conclusions}

The compound herbal $\alpha \beta$-amirona showed topical antiinflammatory action, in the model of ear edema induced by phenol in mice, but at a lower power action of dexamethasone.

\section{Authors' details \\ ${ }^{1}$ Curso de Biotecnologia - UFAM, Manaus, Brasil. ${ }^{2}$ Laboratório de Farmacologia - ICB- UFAM, Manaus, Brasil.}

Published: 1 October 2014

\section{References}

1. Aller MA, Arias JL, Sánchez-Patán F, Arias J: The inflammatory response: an efficient way of life. Medical Science Monitor 2006, 12:225-234.

2. Calixto JB, Campos MM, Otuki MF, Santos AR: Antiinflammatory compounds of plant origin. Part II. modulation of proinflammatory cytokines, chemokines and adhesion molecules. Planta Medica 2004 70:93-103.

3. De Lima RA, Velho LMLS, Faria LIL: Indicadores bibliométricos de cooperação científica internacional em bioprospecção. Perspectivas em Ciências da Informação 2007, 12(1):50-64.

4. Gàbor M: Mouse Ear Inflammation Models and their Pharmacological Applications. Budapeste: Akadémiai Kiadó 2000.

5. Schultes RE, Raffauf RF: The healing forest medical and toxic plants of the Northwest Amazonia. Portland, OR: Dioscorides Press; 1990.

doi:10.1186/1753-6561-8-S4-P35

Cite this article as: Ferreira et al.: Effects of $\alpha \beta$-amirona on inflammation in topical edema ear model in mice. BMC Proceedings 2014 8(Suppl 4):P35.

${ }^{1}$ Curso de Biotecnologia - UFAM, Manaus, Brasil

Full list of author information is available at the end of the article 